\section{Develop and follow your own passion}

\author{
William D. Nix
}

\begin{abstract}
What follows is a commencement speech given to the graduating class of the School of Engineering at San Jose State University in December of 2005. Eminent materials researcher and educator, William $D$. Nix, offered his insights on finding one's own passion and internal compass.
\end{abstract}

$\mathbf{L}$ et me begin by congratulating all of you who are graduating today. You have a right to be very proud of your accomplishments. We should also thank your family and friends who supported you, financially and otherwise.

It seems like only yesterday that I was there, sitting beside you. But actually it was 47 years ago. In thinking of what advice I might give to you, as a materials engineer, I cannot resist quoting from the movie, "The Graduate" where a young Dustin Hoffman is playing Ben, the new graduate. At a party celebrating Ben's graduation from college a guest takes Ben aside and says: "Ben, I have just one word for you." When Ben inquired, the man said: "PLASTICS!"... and then went on to extol the virtues of that particular new technology. Needless to say, Ben did not seem to be moved.

My advice to you will be very different. It is: "Develop and follow your own passion, whatever it may be; it's never too late to start."

By this I mean to find what you like to do and pursue it with all of the vigor you can muster. When you follow your own passion there is no limit to what you can achieve.

By saying that "It's never too late to start," I am recognizing that people find their passion at different points in their lives. You may be uncertain about the choices you have already made for your career or worried that you have not yet developed a direction that will sustain you for your life's work. I am here to tell you not to worry and that it is never too late to find and develop your passion.

You might think from all of the things you have heard about me that I am one of those people who knew from a very young age what I would do in life. But you would be wrong. My parents wanted me to have a good education, something they were denied in the depression. My father finished 7 th grade and my mother the 10th grade, but still they believed in education. Nevertheless, I was a very mediocre student in high school. Indeed, I was so unimpressive that a science teacher once told my mother that while I was a nice boy I should not look for a very challenging line of work.

Still, I was the first in my family to go to college. That is the good news. The bad news is that I was, at first, not much better in college than in high school. My academic record during my first two years shows an unsettling number of C's, D's and F's, in things A's only in basketball. Needless to say, I had not found my passion.

Then, in one course, all of that changed. It was a basic course in statics, of all things. The teacher was Roy Zimmerman, who was a practicing civil engineer and a part time teacher in engineering. He ran the course a little differently than others, with quizzes rather than exams, and somehow I discovered, to my great surprise, that I was doing as well or better than others. Naturally, this got me very interested and I started to study, probably for the first time. I received my first $\mathrm{A}$ in that engineering like math and engineering. I received course. And I think I made A's in every engineering course after that.

Soon thereafter I was so excited about my studies that I began to teach others who were still struggling. I had found my passion - teaching! I have been doing it now for nearly 50 years.

Because of my late development, my undergraduate transcript looks really strangestarting off with D's and F's and ending with A's. A few years ago at Stanford we were sorting through applicants to our graduate program and I thought it would be fun to see how my own academic record would stack up with the applicants of today. So I re-typed my transcript, removed my name and the institution where my degree was granted, and then posted the record outside my office, with the question: "Should we admit this guy to our graduate program." I left a sheet for people to respond to the question and make comments.

Well, many graduate students and some faculty expressed themselves with comments on the prospects of this mystery applicant. The comments were uniformly negative and pessimistic about the prospects of the applicant, pointing to the very poor marks in math and engineering in the first two years and ignoring the high marks in the last years. Needless to say, there was some embarrassment and a little chagrin when I revealed that the academic record displayed was my own! The lesson is that you can always change, especially when you find your passion.

My own experience was not all that uncommon. I recently read some biographical information about Don Beall, who also graduated with a degree in metallurgical engineering from San Jose State, about a year after I did. Like me, he was born in a farming community in central California and like me, his parents were working people who had not gone to college. They also had a strong sense of integrity and ethics and believed in education. His parents had limited means, but they believed in self-reliance. Like me, Don had summer jobs in industry and we even both worked at Douglas Aircraft in Santa Monica at nearly the same time. While Don was a much better student than I, he had not yet found his passion by the time he received his BS degree. 
Shortly after graduating he became interested in the business aspects of technology. He decided to change course and pursue an MBA at the University of Pittsburgh. That decision and his passion for the management of technology soon led him to Rockewell International where he quickly rose through the ranks to become the chair and CEO of that company in the late 1980s. He found his passion and had a very rewarding and influential career.

Let me tell you about two other people who found their passion after their careers had already started.

Shefford Baker was a musician who had become a high school band teacher in Albuquerque. While he very much enjoyed music and teaching, in his late 20 s he decided that he wanted to return to school to study engineering. He studied mechanical engineering at the University of New Mexico and soon thereafter was working for an MS degree. It was at that point that he began to study materials science (with one of my former students) and soon had developed his passion for that subject. $\mathrm{He}$ subsequently came to Stanford University for his $\mathrm{PhD}$ degree in materials science, working with me. By this time he had decided that he wanted to teach at one of the premier research universities. But because of his late start it was not clear if he could compile a sufficiently good record of research to win a faculty position at a good university before his age put him at a competitive disadvantage. So he took a postdoctoral position in Germany and worked very hard for several years to build his reputation. I am pleased to tell you that
Shefford is now a tenured member of the faculty at Cornell University. He found his passion late but pursued it with all of the vigor that he could muster.

Shefford Baker went from being a high school teacher to an academic career in materials science. Now I will tell you about another student who sort of went the other way. Kevin McElhaney was a brilliant undergraduate student in materials science at Stanford who started his research career by working with me and one of my graduate students. By the time he graduated with his BS degree he had already published his first paper, which later became a highly cited paper. His next step was the graduate program in materials science at Northwestern University, where he published more papers. But during the time he was working for his $\mathrm{PhD}$ degree he decided that teaching at the high school level was what he wanted to do. He had found his passion in teaching at the high school level. So he left the $\mathrm{PhD}$ program and enrolled in a special math and science education masters program at Harvard University, which led him to high school teaching. After several years of experience in the classroom he decided that he could make a still greater impact by again pursuing a $\mathrm{PhD}$ degree, this time in science education at the University of California-Berkeley. Soon, after he finishes his studies at Berkeley, he will surely become one of the leaders of science education at the secondary school level in this country. He too found his passion and has pursued it with vigor.

Still other examples are found in the related stories of Ainissa Ramirez and

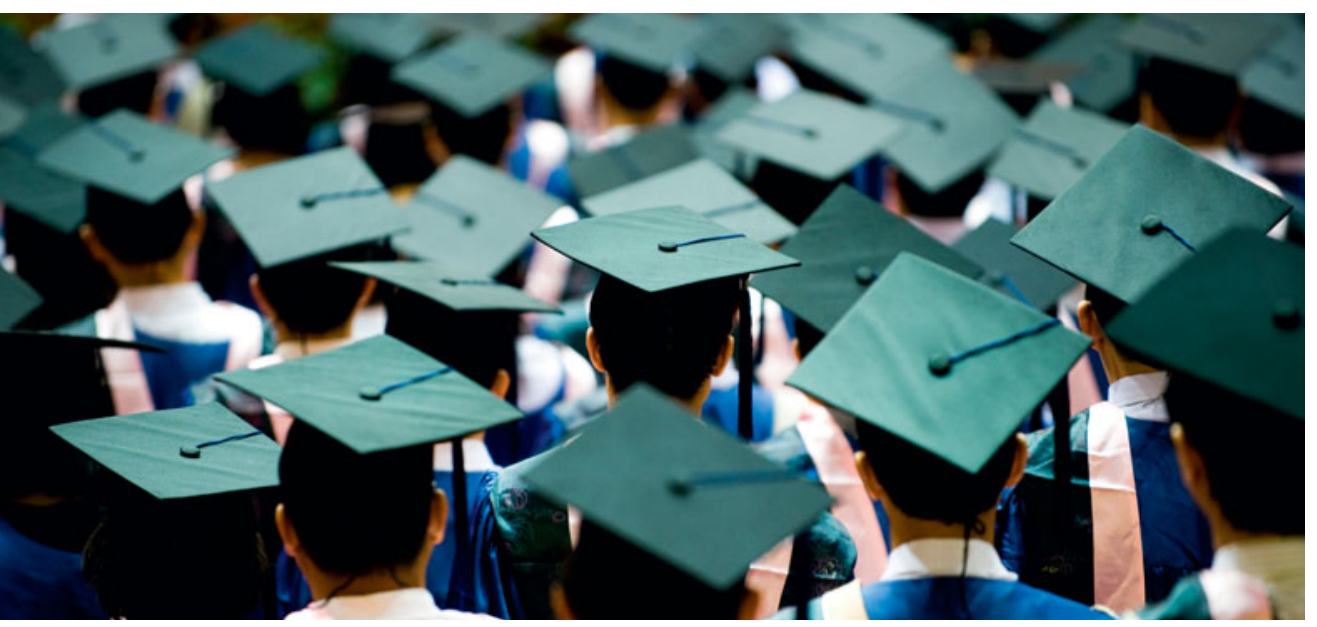

Stacy Hollander, who both decided in the midst of their $\mathrm{PhD}$ research work at Stanford that they wanted careers in teaching. To prepare themselves for that, they went out of their way to organize special seminars at Stanford on university teaching and volunteered to teach introductory materials courses at De Anza College. I am pleased to tell you that Stacy is your own Professor Stacy Gleixner in the Chemical and Materials Engineering Department and Ainissa is a professor of mechanical engineering at Yale University. They both followed their passion.

One of the lessons from these stories is that you are best guided by your own internal compass. The world is full of people who are ready to tell you what you should do or think - what is hot and what is not. But you should decide for yourself your own direction, resisting the temptation to follow the crowd in the hope that you will somehow find success following the dreams of others.

Another lesson is that successful people usually did not start out that way. At some point they found a direction for their life and then put all of their energies into making that direction successful. We have seen that it is never too late to start and/or to change course.

In some places in the world it is not possible to achieve professional success unless you excel when you are very young. Sometimes your life's work is set at the age of about 14 , based on examinations you take in school. But in the United States, the land of opportunity, your future is not determined by how you perform at age 14; rather it is limited only by your imagination, initiative, and hard work. I encourage you to follow the passion you have found, or develop your passion, whatever it may be, and pursue it with all of the gusto that you can muster. If you do that, I can promise you a fulfilling, rewarding, and enjoyable career.

If a mediocre student like me can be standing here, so can you! Thank you.

William D. Nix is the Lee Otterson Professor of Engineering (Emeritus) at Stanford University. In 2007, he received the Von Hippel Award, the Materials Research Society's highest honor. 


\section{International Materials Research Congress (IMRC) 2011}

\section{August 14-18, 2011 • Cancun, Mexico}

A joint meeting of the Sociedad Mexicana de Materiales and the Materials Research Society

www.mrs.org/IMRC2011

\section{TECHNICAL SYMPOSIA}

1. Nanostructured Materials and Nanotechnology

2. Advances in Computational Materials Science

3. Structural and Chemical Characterization of Metal Alloys and Compounds

4. Advanced Structural Materials

5. Advances in Semiconducting Materials

6. New Catalytic Materials

7. NACE: Corrosion and Metallurgy

8. Cultural Heritage and Archeological Issues in Materials Science

9. Photovoltaics, Solar Energy Materials and Technologies

10. Renewable Energy and Sustainable Development

11. Biomaterials for Medical Applications

12. Strategies for Academy-Industry Relations

13. Advances in Ion-Beam Techniques*

14. Fundamentals and Applications of Functional Oxide Materials in Energy, Information and Sensing ${ }^{*}$

15. Bioinspired Materials and Systems ${ }^{\star}$

16. Smart Materials, Devices, and Related Technology*

17. Diamond Devices-Detectors, Sensors, and Photonics*

18. Micro- and Nanomechanical Testing of Materials and Devices*

19. Advanced Electron Microscopy and Nanospectroscopy*

20. Polymer and Polymer-Based Nanocomposite Materials for Energy ${ }^{\star}$

21. Materials Research for Mining and Mineral Processing*

22. Materials Welding and Joining Technologies*

*Symposia sponsored jointly by MRS and MRS-Mexico

\section{MEETING CHAIRS}

David Cahen

Weizmann Inst of Science Israel

Tel 97-28-934-2246 david.cahen@weizmann.ac.il
Andrea M. Hodge

University of Southern California, USA

Tel 213-740-4225 ahodge@usc.edu
Armando Salinas Rodríguez CINVESTAV-Saltillo, Mexico Tel 844-438-9649 armando.salinas@cinvestav.edu.mx
Sergio Mejía Rosales Universidad Autonoma de Nuevo Leon (UANL), Mexico Tel 8183294030 ext 6168 smejia@fcfm.uanl.mx; sergio. mejiars@uanl.edu.mx 